\title{
Parenteral iron administration in suckling piglets - a review
}

\author{
Martin Svoboda ${ }^{1}$, Jonáš Vaňhara ${ }^{1}$, Jana Berlinská $^{2}$ \\ University of Veterinary and Pharmaceutical Sciences Brno, ${ }^{1}$ Faculty of Veterinary Medicine, \\ Ruminant and Swine Clinic, ${ }^{2}$ Faculty of Veterinary Hygiene and Ecology, \\ Department of Animal Protection, Welfare and Behaviour, Brno, Czech Republic
}

Received April 6, 2017

Accepted October 2, 2017

\begin{abstract}
Parenteral iron administration has been a common practice for the prevention of iron deficiency in newborn piglets. The efficacy and safety of this method require reexamination due to the introduction of new genetic lines and management changes in swine production. The aim of this article was to review current knowledge on this method of anaemia prevention in piglets. Iron requirements, iron sources, and the mode of action, dosage, and negative effects of iron dextran injection are discussed. The paper also reviews methods for evaluating the efficacy of iron administration in piglets.
\end{abstract}

Iron dextran, oxidative stress, heamoglobin, haematocrit

Iron deficiency is a serious problem in swine production. Newborn piglets have limited reserves of iron (Fe), which cannot cover daily iron requirements (Venn et al. 1947). Therefore, without additional iron supplements the piglets develop anaemia within 10-14 days after birth (Egeli et al. 1998a). The most commonly used method for preventing iron deficiency in piglets is parenteral iron injection (Svoboda and Drabek 2005b). The introduction of new genetic lines and management practices have raised concerns about the efficacy and safety of this method. The need of piglets for supplemental iron is influenced by iron requirements and the availability of iron sources.

\section{Iron requirements}

Iron requirements for piglets have been provided by several authors. Venn et al. (1947) found that piglets must retain about $7 \mathrm{mg}$ of iron daily to grow at a normal rate without becoming anaemic. This is recommended for the first three weeks of life. Braude et al. (1962) stated that suckling piglets must retain 7-16 mg of iron per day to maintain adequate concentrations of haemoglobin ( $\mathrm{Hb}$ ) and storage iron. According to Von Bollwahn et al. (1983), a piglet with a birth weight of at least $1.4 \mathrm{~kg}$ and daily weight gains of 200-250 $\mathrm{g}$ requires about $11 \mathrm{mg}$ of iron daily.

Similar results were obtained by Zimmermann (1995), who found that piglets with daily weight gains of $250 \mathrm{~g}$ need $10 \mathrm{mg}$ iron per day.

Some authors express the total Fe requirement for piglets as the number of milligrams of iron necessary for $1 \mathrm{~kg}$ of body weight gain.

Braude et al. (1962) found that $25 \mathrm{mg}$ of iron $/ \mathrm{kg}$ body weight is necessary to maintain adequate concentrations of haemoglobin. Von Bollwahn (1983) found that $40 \mathrm{mg}$ of iron is required for $1 \mathrm{~kg}$ of body weight gain. According to Egeli and Framstad (1998), $35-40 \mathrm{mg} \mathrm{Fe} / \mathrm{kg}$ weight gain is necessary if haemoglobin levels are to be maintained at $100 \mathrm{~g} / 1$.

Iron requirements for piglets can be influenced by several factors. The most important one is growth intensity in the early postnatal life. 
Piglets double their weight from 1.5 to $3 \mathrm{~kg}$ during the first seven days of life. At the same time, the plasma volume expands by $30 \%$ (Jain 1986). According to Peters and Mahan (2008), high growth intensity increases the need for iron because a larger volume of blood is required to maintain the larger amount of tissue being formed. The larger blood volume requires more haemoglobin and iron. Therefore, the heaviest piglets are in greater danger of becoming iron deficient and anaemic (Steinhardt et al. 1984).

This was confirmed for example by Jolliff and Mahan (2011), who found that heavier piglets had lower heamoglobin and packed cell volume (PCV) at weaning. Kubik et al. (2015) also observed that the largest piglets at weaning had lower haemoglobin values compared to small piglets. Perri et al. (2016) reported that larger piglets at weaning had lower red blood cell indicators and serum iron than smaller piglets. Bhattarai and Nielsen (2015) found that larger weaning piglets had lower serum iron and total iron binding capacity, which made them prone to iron deficiency.

A certain degree of blood loss can occur during tail docking and castration (Heinritzi and Plonait 1997). Postweaning multisystemic wasting syndrome (PMWS) (Segales et al. 2004) and Mycoplasma suis infection (Groebel et al. 2009) of piglets can result in the development of anaemia. Their effects on iron requirements for piglet have not yet been defined. Further studies are required to investigate this issue.

\section{Iron sources}

\section{Foetal reserves}

Foetal reserves of iron in piglets are generally low and contribute to overall iron deficiency. The situation can become even worse in highly prolific sows. According to Mahan and Newton (1995), a greater number of piglets and high milk productivity may affect the Fe status of the sow. The authors found that highly prolific sows have a lower body Fe content than sows with decreased prolificacy. Therefore, less iron might be available for transfer to the developing foetus or to the mammary tissue (Peters and Mahan 2008).

Storage of iron in the liver is not large enough for the prevention of anaemia in piglets that did not receive iron (Ekman and Iwanska 1966). According to Venn et al. (1947) the piglet contains ca $50 \mathrm{mg}$ iron at birth, mostly in the form of haemoglobin. Only $5 \mathrm{mg}$ $\mathrm{Fe}$ are available for new haemoglobin synthesis at birth.

Von Bollwahn et al. (1983) found that newborn piglets $(1.5 \mathrm{~kg})$ had ca $60 \mathrm{mg} \mathrm{Fe}$, of which amount $12 \mathrm{mg}$ was storage iron and $48 \mathrm{mg}$ was functional iron (42 mg Hb, $6 \mathrm{mg}$ myoglobin and cytochrome). Attempts have been made to increase the transfer of iron from the sow to her piglets. The best results were obtained by Wei et al. (2005), who found that Fe from an amino acid complex fed to sows increased the iron status of neonatal piglets. However, this improvement was not sufficient to replace Fe injection.

\section{Milk}

Milk is a poor source of iron for neonatal pigs. Piglets can receive up to $1 \mathrm{mg}$ Fe daily from milk (Venn et al. 1947). The dietary addition of iron into sow feed can increase the Fe content in milk only to a limited extent, even with the use of iron from amino acids chelates (Wei et al. 2005).

\section{Environment}

Additional iron sources in farrowing crates are of low significance. Piglets can obtain some iron from the sow's faeces by coprofagy. This possibility is limited with the use of slotted areas for faeces (Peters and Mahan 2008). The use of plastic and stainless material prevents the formation of iron oxide (rust) by the corrosion of metal objects. 


\section{Creep feed}

The uptake of iron from creep feed can be an important factor for the efficacy of parenteral iron treatment. For instance, Payne et al. (2005) found that the standardly used dose (200 mg Fe, intramuscularly (i.m.) at day 3 ) did not prevent anaemia at weaning (28 days) in the group of piglets that were not offered iron in the feed. In contrast, the piglets that were injected with $\mathrm{Fe}$ and offered an iron feed mixture had adequate concentrations of $\mathrm{Hb}$ at weaning.

The uptake of iron from the creep feed can be influenced by the Fe content and its availability for the piglets. Feed consumption is also important.

According to Radostits et al. (1994), iron content in the creep feed should be at least $240 \mathrm{mg} / \mathrm{kg}$ in order to prevent subclinical anaemia when a single dose of $200 \mathrm{mg} \mathrm{Fe}$ is injected. As for the minimum content of iron in the creep feed, we found no other specific recommendation in the literature. Ferric oxide or iron carbonate can be used, although the availability of iron from these compounds is very low. The most commonly used substance nowadays is iron sulphate. It offers good availability of iron and is easily mixed with other feed substances (Miller and Ullrey 2007). Creep feed consumption can be influenced by its taste (Adeleye et al. 2014) and the design of feeders (Wattanakul et al. 2005).

\section{Nursery feed}

According to Peters and Mahan (2008), supplementation of the nursery diet with more than $90 \mathrm{mg} \mathrm{Fe} / \mathrm{kg}$ in the form of iron sulphate may be necessary to maintain blood $\mathrm{Hb}$ and PCV levels in piglets after weaning.

A study by Rincker et al. (2004) indicates than an even higher dietary supplement of $150 \mathrm{mg} \mathrm{Fe} / \mathrm{kg}$ (as an iron sulphate) in the nursery diet may be necessary to maintain the piglet's haematological profile.

Based on the American National Research Council (NRC) (2012), the iron requirement for piglets weighing $5-11 \mathrm{~kg}$ is $100 \mathrm{mg} \mathrm{Fe} / \mathrm{kg}$ of diet.

According to Danish recommendations, the diet of piglets from $6-15 \mathrm{~kg}$ of body weight should contain $150 \mathrm{mg} \mathrm{Fe} / \mathrm{FU}$ (feed unit), of which a minimum of one hundred $\mathrm{mg}$ should be in the form of an easily soluble iron salt. The value is presented as the total amount in the feed (Tybirk et al. 2013).

Zinc oxide is routinely used at high concentrations $(>2000 \mathrm{mg} / \mathrm{kg})$ in nursery diets for the prevention of $E$. coli diarrhoea (Amezcua et al. 2008). Perri et al. (2016) found that high concentrations of zinc oxide were associated with post-weaning anaemia. A limitation of the study was that the period during which the piglets were fed high levels of zinc oxide was not measured. More studies are required to investigate this problem further.

Recent studies indicate that the ability of post-weaning piglets to utilize iron from the feed may be limited. Kubik et al. (2015) observed that piglets remained anaemic or iron deficient during 3 weeks post weaning although starter rations were well fortified with iron. Perri et al. (2016) conducted a survey on several farms and found some anaemic piglets at weaning, though surprisingly more pigs were anaemic 3 weeks thereafter. In a study by Jolliff and Mahan (2011), haemoglobin concentrations were at their lowest 14-21 days after weaning, which corresponds to 31-38 days of age. According to Hansen et al. (2010), the intestinal regulation of iron absorption may not be fully functional during the first weeks post weaning. Jolliff and Mahan (2011) stated that 31-38 days of age is a critical point for erythropoiesis in pigs because it is the period when dietary iron begins significantly to affect $\mathrm{Hb}$ and PCV blood values.

This implies that a second iron injection during the suckling period may be beneficial. It could maintain post-weaning Fe reserves until iron uptake from the feed is sufficient (Jolliff and Mahan 2011). 


\section{Supplemental iron}

The need for iron given by injection depends on Fe requirements and the extent to which it can be covered by other sources. When we take $10 \mathrm{mg}$ as the daily iron requirement, then a dose of $200 \mathrm{mg}$ would cover 20 days. Therefore, it would be sufficient in the case of weaning at 3 weeks. However, this may not be true in the case of increased iron requirements (larger piglets, blood loss). This assumption is supported by Jolliff and Mahan (2011), who found that larger piglets had lower haemoglobin values at weaning (21 days).

In the case of weaning at 28 days, other iron sources are necessary to cover the full requirement when a dose of $200 \mathrm{mg}$ Fe is used. According to Venn et al. (1947), the piglet can use about $5 \mathrm{mg}$ iron from foetal reserves and $1 \mathrm{mg}$ Fe from milk daily ( $28 \mathrm{mg}$ in total). This makes together $233 \mathrm{mg}$ Fe. When we calculate with $12 \mathrm{mg}$ of storage iron available for haemoglobin synthesis after birth (Von Bollwahn et al. 1983) we get $240 \mathrm{mg} \mathrm{Fe}$.

Considering the environment as a negligible source, the remaining iron requirement $(280 \mathrm{mg})$ should be provided from creep feeding. We conclude that every farm represents an individual entity with respect to iron requirements and iron sources. As there are many factors affecting iron requirements and iron availability from other sources it is not possible to calculate exactly the need for supplemental iron. We suggest that iron supplementation protocols should be adjusted for each particular farm on the basis of the evaluation of their efficacy under specific conditions. For this purpose, indicators of iron deficiency should be used.

\section{Mode of action}

The iron in preparations for injection must be bound to a stabilizer which provides some form of complex. This reduces iron toxicity (Carlsson et al. 1974). Examples of such substances that are used on pig farms are iron dextran and gleptoferron (Svoboda and Drabek 2005b). Most scientific literature dealing with this topic in piglets gives information on the use of iron dextran, although gleptoferron was found to have comparable efficacy in anaemia prevention in piglets (Vermeer et al. 2002). As a high molecular complex, iron dextran is taken up from the injection site by the reticulohistiocytic system. In phagocytes, the dextran complex is decomposed by lysosomal enzymes and the iron is stored as ferritin (Katkiewicz et al. 1986). The iron is then released and binds to transferrin, which moves it to the areas of need (Murray et al. 2000). The elimination of iron dextran by the reticulohistiocytic system is rapid. It has been found that iron is eliminated from the injection site 7 days after administration (Sladic-Simic and Cvetkovic 1978). Ingestion of iron dextran by macrophages causes an increase in iron content in lymph nodes (Kolb et al. 1992). Vrigazov and Dilov (1976) found that Fe from iron dextran appeared in erythrocytes $24 \mathrm{~h}$ after infection in piglets. The response of red blood cell indices to iron dextran treatment was evaluated by Holter et al. (1991). The injection of iron dextran led to a significant increase in $\mathrm{Hb}, \mathrm{PCV}$, and the mean corpuscular volume (MCV) four days after treatment.

\section{Administration technique}

Injections are administered routinely by i.m. administration. A proper technique is necessary to ensure maximum efficacy. Injections can be administered in the ham or neck muscle. According to Miller and Ullrey (2007), a 20-gauge disposable needle, 1/2 to 1 inch long should be used for iron administration in suckling piglets. He also recommends forcing the skin slightly to one side with the thumb just before making the injection to help prevent the run back of iron from the injection. Another option is subcutaneous (s.c.) administration. Svoboda and Drabek (2007) found that it has the same efficacy as i.m. injection. Most recently, transdermal injection with a needle-free device has been evaluated. 
It has been found to have a comparable efficacy to that of standard i.m. administration (Kievit 2012).

\section{Dosage}

The dose should provide sufficient iron for piglets to maintain adequate haemoglobin levels. Recommendations given by different authors on dosage and number of injections are not always in agreement. Iron can be injected in one or more doses.

\section{Single injection}

It has been found that a single dose of $100 \mathrm{mg}$ Fe in the form of iron dextran is not sufficient to prevent anaemia and to ensure optimal weight gain (Daykin et al. 1982). Therefore, the most common method of anaemia prevention is to inject $200 \mathrm{mg}$ iron as iron dextran on the $3^{\text {rd }}$ day of life (Carlsson et al. 1974; Yu et al. 2002). The use of new genetic lines and changes in management techniques have raised concerns about the efficacy and safety of this method. For instance, Egeli (1998) found that piglets injected with $180 \mathrm{mg}$ iron on the first day of life had relatively low haemoglobin values on days 21 and 35. This indicates that iron reserves were beginning to become depleted. This effect was more pronounced in piglets with high growth intensity. The option that we consider is multiple iron administration. For practical reasons (labour, cost) only a double dose is feasible.

\section{Double injection}

Most authors agree that a second dose improves haematological indices. However, conflicting results have been found with respect to the effect on body weight gain.

For example, Radostits et al. (1994) concluded that the second injection at 2-3 weeks of age yields better haemoglobin levels but does not improve weight gain. Murphy et al. (1997) found that one injection of iron (200 mg) was sufficient to sustain the average daily gain. A second injection of iron did not improve weight gain. According to Bruininx et al. (2000), a second iron injection 1 week before weaning did not affect body growth. Also, Jolliff and Mahan (2011) demonstrated that a second dose of $100 \mathrm{mg}$ Fe at the age of 10 days improved haematological indices, but did not have a positive effect on the performance of piglets.

On the other hand, Von Bollwahn et al. (1983) found that another iron dextran injection at 3 weeks of age had a positive effect on growth. Kamphues et al. (1992) also showed the positive effect of a second iron dextran injection $(200 \mathrm{mg})$ at the age of 21 days on performance before and after weaning. This effect was more pronounced in piglets with high growth intensity. Similar results were presented by Haugegaard et al. (2008). A second injection at the age of 21 days improved red blood cell indices and increased weight gain by $25 \mathrm{~g}$.

Bhattarai and Nielsen (2015) showed that the improved haematological status of piglets after weaning is positively associated with their growth rate. An increase in $10 \mathrm{~g} \mathrm{Hb} / 1$ corresponded to a daily weight gain improvement of $17.2 \mathrm{~g}$. It is not clear how increased $\mathrm{Hb}$ levels could positively affect weight gain. According to Gentry et al. (1997), pigs with a high $\mathrm{Hb}$ status have better energy retention. A positive effect on intestinal functions may also be involved (Larkin and Hannan 1984). More studies are necessary to further investigate this problem and clarify differences.

\section{Modified protocol}

Starzynski et al. (2013) found that an i.m. dose of $150 \mathrm{mg} \mathrm{Fe} / \mathrm{kg}$ b.w. in 3-day-old piglets induces hepcidin expression at the ribonucleic acid (RNA) level in the liver. This could potentially have negative effects because high hepcidin concentrations may disrupt 
the utilization of Fe from iron dextran by blocking ferroportin (Beaumont 2010). The authors demonstrated that a modified protocol with reduced amounts of iron $(37.5 \mathrm{mg}$ $\mathrm{Fe} / \mathrm{kg}$ b.w. on day 3 and 14) improved the haematological status of piglets, while plasma hepcidin-25 levels remained low. More research is required to further evaluate these findings and their application in the practice.

\section{Negative effects of iron dextran injection}

\section{Iron toxicity}

In normal piglets, iron dextran preparations are non-toxic (Radostits et al. 1994). Reports of toxicity after iron dextran injection are sporadic. Acute poisoning can occur when the piglets are deficient in antioxidants, i.e. vitamin E and selenium (Velásques and Aranzazu 2004). Such animals have a reduced resistance to iron because they cannot counteract peroxidative reactions (Loudenslager et al. 1997). Iron can damage tissues by the production of free radicals that may attack cellular membranes, proteins and deoxyribonucleic acid (DNA) (Hirayama and Yasutake 1998). The symptoms of iron toxicosis can set in 20-30 min or 4-6 h at the latest after iron treatment. The clinical signs are dyspnoea, heart failure, tremor, movement incoordination, paralysis, and coma. The incidence is usually limited to a few litters (Süveges and Glávits 1976). A latent disturbance of heart function can be present after iron dextran injection. Therefore, any excitation of piglets must be prevented (Kolb et al. 1989).

A more recent case of iron toxicity in newborn piglets from vitamin $\mathrm{E}$ and selenium deficient sows was described by Velásques and Aranzazu (2004). The piglets developed signs $6 \mathrm{~h}$ after injection. They showed dyspnoea, pallor, and icterus. There was significant inflammation at the injection site. Vascular congestion syndrome was observed in most organs. Correction of the sow diet brought the herd to normality. During the outbreak, all sows were injected with a vitamin E/selenium preparation. The split iron dextran dose administration was used and piglets were injected at birth and weaning with the vitamin E/selenium preparation.

The most important predisposing factor is vitamin E or selenium deficiency in the sow, which results in similar deficiency in the piglets (Wilhelm 1998). Only a limited amount of vitamin $\mathrm{E}$ is transported through the sow placenta, even when the dietary concentration is high (Loudenslager et al. 1997). Therefore, one-day-old piglets have low vitamin E content in blood plasma and are more sensitive to iron poisoning.

During the first two days, piglets receive important amounts of selenium and vitamin E from colostrum. Therefore, the plasma antioxidant status of piglets is increased by 2 days of age. According to Kolb and Hoffman (1989), iron injection is not recommended earlier than on the third day of life. It has been recommended that piglets in problematic herds should be injected with vitamin E (10-20 mg per piglet) $24 \mathrm{~h}$ before iron administration. Tollerz (1973) prevented any death and avoided adverse effects with the same procedure. In his study, he used a dose of 20-60 mg $\mathrm{kg}^{-1}$ b.w. According to Loudenslager et al. (1986), the concentration of vitamin $\mathrm{E}$ and selenium in colostrum can be increased when the sow is fed adequate amounts of these nutrients. The authors found that the supplementation of sow feed with selenium $(0.1 \mathrm{ppm})$ and vitamin E (50 International Units $\cdot \mathrm{kg}^{-1}$ ) maintained high concentrations of these substances in colostrum and milk and also a high antioxidant status in piglets throughout the nursing period. According to NRC (2012), selenium and vitamin $E$ requirements for both gestating and lactating sows are $0.15 \mathrm{mg} \mathrm{Se} / \mathrm{kg}$ and $44 \mathrm{IU} / \mathrm{kg}$ of the diet. Tybirk et al. (2013) recommend $0.2 \mathrm{mg} \mathrm{Se} \cdot \mathrm{FU}^{-1}$ (feed unit) for gestating and lactating sows. This value is presented as the total amount in the feed. For gestating and lactating sows, they recommend the supplementation of vitamin $\mathrm{E}$ at $40 \mathrm{IU} \cdot \mathrm{FU}^{-1}$ and $165 \mathrm{IU} \cdot \mathrm{FU}^{-1}$, respectively. 
Most recently, Chen et al. (2016) found that the antioxidant status of the serum and liver of newborn piglets was improved when organic selenium (Se-enriched yeast) was added to the sow diet instead of inorganic sodium selenite (both $0.3 \mathrm{mg} \cdot \mathrm{kg}^{-1}$ ). Also an increase in vitamin E levels in the sow diet ( $\left.30 \mathrm{vs.} 90 \mathrm{IU} \cdot \mathrm{kg}^{-1}\right)$ had a positive effect on the antioxidant status of piglets. The applications of these findings in the reduction of oxidative stress after iron injection should be further investigated.

\section{Oxidative stress}

Iron bound to proteins is safe for the organism. Unbound iron is formed when its amount in serum exceeds the binding capacity of transferrin. This iron form catalyses the production of free radicals (Dziaman et al. 2011). Lipinski et al. (2010) found that the standard injection of iron in piglets $(100 \mathrm{mg} \mathrm{Fe} / \mathrm{kg}$ b.w. on day 3$)$ resulted in an increase of oxidative stress in liver cells. It was indicated by increased 8-oxod G levels in hepatic DNA. This indicator is considered as a good biomarker of oxidative stress. According to Langie et al. (2010), i.m. iron administration increased oxidative stress in the colon of piglets (measured as 8-oxod G levels in colon DNA).

These studies indicate that standard iron i.m. administration can influence the level of oxidative stress while piglets appear clinically unaffected after treatment. Further studies are necessary to clarify the extent to which such an elevation of oxidative stress could influence the wellbeing and health of piglets.

\section{Arthritis}

It is problematic to evaluate objectively the role of injective iron in the development of arthritis in piglets under practical conditions. Despite the widespread use of parenteral iron administration we have found only two records that indicate an association between injective iron and arthritis in piglets. Holmgren (1996) found that an early injection of iron dextran in piglets led to an elevated incidence of polyarthritis. Rantzer et al. (2010) reported that the incidence of polyarthritis was significantly reduced with the use of oral iron. They also found that there were significantly more treatments for joint infections in piglets given an early iron injection (1-4 days of age) than in littermates who received a late injection (8-12 days).

The higher occurrence of arthritis after iron injection in piglets may be explained in two ways.

Firstly, it is known that a certain amount of iron is required for growth and the function of bacteria (Bullen et al. 1978).

Secondly, lipid peroxidation induced by iron overdose can affect the immune system. For example, phagocytosis and the oxidative burst of granulocytes and monocytes may be impaired (Lehmann 2001). Therefore, it is very important to ensure good antioxidant defense in piglets. In the study of Holmgren (1996), vitamin E administration before iron injection decreased the incidence of polyarthritis.

\section{Control of the efficacy}

Three categories of iron deficiency exist in animals: prelatent (iron store deficit), latent (decreased serum iron, decreased transferin saturation), and clinically apparent (low haemoglobin concentration) (Hastka 1994). Diagnosis in piglets is based on clinical signs, laboratory examination, and upon the history of no access to iron (Taylor 1989). Iron deficiency anaemia is identified in the laboratory as microcytic, hypochromic anaemia (Egeli et al. 1998a). Anaemia is usually associated with a decreased concentration of haemoglobin and a decreased value of highly correlated PCV (Svoboda and Drabek 
2005a). The diagnosis of iron deficiency anaemia is based on the examination of red blood cell indices, i.e. haemoglobin concentration, PCV, erythrocyte count, and reticulocytes (Lehmann 2001). The diagnosis of latent iron deficiency is based on the determination of biochemical indices in blood plasma.

\section{Red blood cell indices}

It is not entirely clear what haemoglobin concentration in piglets should be considered as anaemic. There are many inconsistencies in the literature concerning this issue.

In 1979, the National Research Council devised a classification system by which pigs of all age groups could be categorized on the basis of their $\mathrm{Hb}$ concentration, measured in grams/decilitre as follows:

- Pigs with $\mathrm{Hb}$ concentrations of 10 or above are normal.

- $\mathrm{Hb}$ concentration of 9 is the minimum level for optimum performance.

- Hb concentration of 8 indicates borderline anaemia.

- Hb concentration of 7 is the level at which anaemia retards growth.

- Hb concentration of 6 is considered as severe anaemia and 4 as severe anaemia with increased mortality.

This is in line with Egeli et al. (1989b), who stated that the anaemic limit, i.e. the point when anaemia begins to exert a detrimental effect on weight gain or gives rise to clinical symptoms of anaemia, is at a haemoglobin concentration of $80 \mathrm{~g} \cdot \mathrm{l}^{-1}$ (Furugouri 1975; Van Kempen 1987).

According to McDowell (1992), a haemoglobin concentration of $100 \mathrm{~g} \cdot \mathrm{l}^{-1}$ is normal and $80 \mathrm{~g} \cdot \cdot^{-1}$ indicates borderline anaemia. Daykin et al. (1982) are stricter. They consider a haemoglobin concentration of below $90 \mathrm{~g} \cdot \mathrm{l}^{-1}$ as the definition of anaemia. More recently, Bhattarai and Nielsen (2015) suggested a haemoglobin concentration of below $90 \mathrm{~g} \cdot \mathrm{l}^{-1}$ as indicative of anaemia.

Although no signs of anaemia or distinct growth retardation are present at an $\mathrm{Hb}$ concentration of $80 \mathrm{~g} \cdot \mathrm{l}^{-1}$, the genetic potential of piglets cannot be fully utilized (Stein hardt et al. 1984; Egeli 1998b). Therefore, the goal of anaemia prophylaxis should not be that no piglets have a $\mathrm{Hb}$ concentration lower than $80 \mathrm{~g} \cdot \mathrm{l}^{-1}$. Such a goal is not sufficient to ensure optimal iron supplementation in piglets (Svoboda and Drabek 2005a). Iron is preferentially shunted from other iron pools to haemoglobin (Nathanson et al. 1984). Thus, haemoglobin may be the last pool to show the effects of iron inadequacy. The inhibition or impairment of some processes in the animal through lack of iron may occur long before haemoglobin formation becomes adversely affected (Underwood 1999).

According to Bhattarai and Nielsen (2015), a haemoglobin concentration below $110 \mathrm{~g} \cdot 1^{-1}$ is indicative of iron deficiency. This in in agreement with Von Bohlwahn et al. (1983), who describe latent iron deficiency in piglets as the situation in which total iron-binding capacity (TIBC) is increased above $82 \mu \mathrm{mol} \cdot \mathrm{l}^{-1}$ and serum iron is under $16 \mu \mathrm{mol} \cdot \mathrm{l}^{-1}$, while red blood cell indices are still unchanged i.e. haemoglobin is at least $110 \mathrm{~g} \cdot \mathrm{l}^{-1}$ and PCV $0.351 \cdot \mathrm{l}^{-1}$.

This is also in line with Steinhardt et al. (1982a) and Steinhardt et al. (1982b), who conclude that using only $\mathrm{Hb}$ concentration, latent iron deficiency can surely be excluded when the haemoglobin concentration is as high as $110 \mathrm{~g} \cdot 1^{-1}$.

Besides haemoglobin concentration, PCV, and erythrocyte number, three other erythrocyte indices can be calculated: $\mathrm{MCV}$ - mean corpuscular volume (fl), $\mathrm{MCH}$ - mean corpuscular haemoglobin (pg), and $\mathrm{MCHC}$ - mean corpuscular haemoglobin concentration $\left(\mathrm{g} \cdot \mathrm{l}^{-1}\right)$. All three indices decrease in the case of iron deficiency anaemia (Smith et al. 1987).

Reference haematological values for piglets were given by Steinhardt et al. (1982a,b). According to these authors, normal values range between $110 \mathrm{~g} \cdot \mathrm{l}^{-1}$ and $130 \mathrm{~g} \cdot \mathrm{l}^{-1}$ for haemoglobin concentration, 0.36 and $0.421 \cdot 1^{-1}$ for $\mathrm{PCV}, 5.5$ and $6.8 \mathrm{~T} \cdot \mathrm{l}^{-1}$ for erythrocyte 
count, 58 and $62 \mathrm{fl}$ for MCV, 19 and $21 \mathrm{pg}$ for $\mathrm{MCH}$ level and 320 and $350 \mathrm{~g} \cdot \mathrm{l}^{-1}$ for MCHC.

Reference values were also presented more recently by Moritz et al. (2014): Haemoglobin 108-148 g $\cdot \mathrm{l}^{-1}$, erythrocytes 5.8-8.1 $\mathrm{T} \cdot \mathrm{l}^{-1}$, PCV 33-45\%; MCV 50-65 fl; MCH 17-21 pg; and $\mathrm{MCHC} 300-350 \mathrm{~g} \cdot \mathrm{1}^{-1}$.

Classical erythrocyte indices cannot provide information on the rapid change in erythropoetic activity. The reason for this is a long erythrocyte life span (McDougall et al. 1992). Therefore, we need an earlier and more sensitive marker for functional iron deficiency. With the introduction of new techniques, it is now possible to analyse reticulocyte indices, including their volume (d'Onofrio et al. 1995; Brugnara et al. 1997). Haemoglobin concentration in reticulocytes reflects the amount of available iron during red blood cell (RBC) production. The usefulness of such indices as early markers of iron deficiency was demonstrated by studies evaluating the iron status in human patients (Brugnara et al. 1997; Cullen et al. 1999). The use of reticulocyte indices for the diagnosis of anaemia in piglets was evaluated by Svoboda et al. (2008). They found that in comparison with $\mathrm{Hb}$, $\mathrm{PCV}$, and $\mathrm{RBC}$ values, reticulocyte indices more rapidly reflect impaired erythropoiesis. The reaction of $\mathrm{MCV}$ and $\mathrm{MCH}$ to impaired erythropoiesis is comparable with that of reticulocyte indices. The authors concluded that reticulocyte indices can be considered as very sensitive indicators of iron deficiency in suckling piglets.

\section{Biochemical indices}

When considering only haemoglobin concentration, prelatent and latent iron deficiency cannot be diagnosed. Therefore, serum examination should be included in the diagnosis of iron deficiency in suckling piglets (Svoboda and Drabek 2005a). The biochemical markers of iron metabolism include serum iron, serum total iron binding capacity (TIBC), transferrin (Tf), transferrin saturation (TfS), ferritin, and, more recently, the measurement of serum soluble Tf receptor (sTfR). Iron deficiency anaemia is characterized by low serum iron and ferritin concentrations, decreased TfS, or increased sTfR (Ioannou et al. 2002; Thomas et al. 2002). In the case of iron deficiency, TIBC is increased (Smith 1997).

Serum iron is measured in order to evaluate the iron transport compartment. This parameter can be influenced by other factors than iron deficiency (Ferguson et al. 1992; Porter et al. 1994). Therefore, care must be taken when interpreting serum iron concentrations because misdiagnosis of iron deficiency is possible (Smith 1997). For example, serum iron can decline due to bacterial infection and acute-phase reactions, hypoproteinaemia, hypothyroidism, renal disease, and chronic inflammation. It may be elevated in haemolytic anaemia and liver disease (Kaneko 1980; Smith et al. 1997).

Total iron binding capacity expresses the iron content when transferrin is saturated with iron. Because transferrin can bind more iron than is normally present, the value of this indicator is higher than that of serum iron. Therefore, serum iron can be expressed as a percentage of TIBC and presented as the percentage of saturation (Smith 1997).

The transferring receptor has been used as a sensitive indicator of iron deficiency. As this indicator is not affected by acute or chronic inflammation, the test can be used to provide a reliable index of marrow iron stores (Suominen et al. 1998; Thomas et al. 2002).

However, for screening purposes, methods of measuring ferritin and serum transferring receptors are expensive. Therefore, only serum iron and TIBC can be used for the diagnosis of iron deficiency in piglets under practical conditions.

Steinhardt et al. (1982b) provide the reference values of $22-36 \mu \mathrm{mol} \cdot \mathrm{l}^{-1}$ for plasma iron concentration, $80-100 \mu \mathrm{mol} \cdot \mathrm{l}^{-1}$ for (TIBC), and $25-40 \%$ for the saturation of total iron binding capacity.

Kaneko (1993) also provided reference values of $21.7 \pm 5.9 \mu \mathrm{mol} \cdot \mathrm{l}^{-1}$ for serum iron concentration and $56.8 \pm 6.8 \mu \mathrm{mol} \cdot \cdot^{-1}$ for TIBC. 


\section{Summary}

The efficacy and safety of parenteral iron administration in anaemia prevention should be reevaluated. The main reasons are the introduction of new genetic lines and management changes in swine practice. Iron requirements and the availability of iron sources can be affected by many factors. Therefore, the need for supplementary iron must be considered on the level of the individual herd. The efficacy of the iron administration protocol should be determined by evaluating its effects on the indicators of iron deficiency. In order to detect subclinical forms of iron deficiency both haematological and biochemical indicators should be used. The new data indicate that such examination should be conducted not only during the suckling period but also 3 weeks after weaning. In order to prevent the risk of iron toxicity it is important to ensure an adequate supply of antioxidants to newborn piglets. Although the problem of iron deficiency in piglets has been studied for several decades there are still issues that require further investigation.

\section{Acknowledgement}

This research was supported by the Internal Grant Agency 111/2016/FVL, University of Veterinary and Pharmaceutical Sciences Brno, Czech Republic.

\section{References}

Adeleye OO, Brett M, Blomfield D, Guy JH, Edwards SA 2014: The effect of algal biomass supplementation in maternal diets on piglet survival in two housing systems. Livest Sci 162: 193-200

Amezcua R, Frienship R, Dewey CE 2008. An investigation of presence of Escherchia coli O149:K91:F4 on pig farms in southern Ontario and the use of antimicrobials and risk factors associated with the presence of this serogroup. Can Vet J 49: 39-45

Beaumont C 2010. Multiple regulatory mechanism act in concert to control ferroportin expression and heme iron recycling by macrophages. Haematologica 95: 1233-1236

Bhattarai S, Nielsen JP 2015. Early indicators of iron deficiency in large piglets at weaning. J Swine Health Prod 23: $10-17$

Braude R, Chamberlain AG, Kotarbinska M, Mitchell KG 1962. The metabolism of iron in piglets given labelled iron either orally or by injection. Br J Nutr 16: 427-449

Brugnara C, Zemanovi D, Sorette M, Ballas SK, Platt O 1997. Reticulocyte haemoglobin. An integrated parameter for evaluation of erythropoetic activity. Am J Clin Pathol 108: 133-142

Bruininx E, Swinkels J, Permentioer C, Jetten C, Gentry J, Schrama J 2000. Effect of an additional iron injection on growth and humoral immunity of weaning pigs. J Swine Health Prod 23: 10-17

Bullen JJ, Rogers HJ, Griffiths E 1978: Role of iron in bacterial infection. Curr Top Microbiol Immunol 80: 1-35

Carlsson H, Lindvall S, Thafvelin B 1974: Properties of a complex of iron and a sorbitol-gluconic acid polymer for treatment of piglet anaemia. Acta Vet Scand 15: 100-110

Cullen P, Söffker J, Höpfl M, Bremer C, Schlaghecker R, Mehrens T 1999. Hypochromic red cells and reticulocyte haemoglobin content as markers of iron deficient erythropoesis in patients undergoing chronic haemodialysis. Nephrol Dial Transplant 14: 659-665

d'Onofrio G, Chirillo R, Yini G, Caenaro G, Tommasi M, Micciuli G 1995: Simultaneous measurement of reticulocyte and red blood cell indexes in healthy subjects and patients with microtic and macrotic anemia. Blood 85: 818-823

Daykin MM, Griffiths AJ, Towlerton RG 1982: Evaluation of the parenteral iron requirement of early weaned pigs. Vet Rec 110: 535

Dziaman T, Jurgowiak M, Olinski R 2011: Association between body iron stores and level of oxidatively modified DNA bases. Biotechnologia 2: 159-165

Egeli AK 1998a: Iron deficiency anemia in piglets. The Norwegian College of Veterinary Medicine. Department of Reproduction and Forensic Medicine. In Jorgensen A, Brun E (2000): Haemoglobin Status in 3 Weeks Piglets in Herds with Different Strategies for Iron Supply. IPVS Congress, Melbourne, 62 p.

Egeli AK, Framstad T 1998. Evaluation of the efficacy of perorally administered glutamic acid-chelated iron and iron-dextran injected subcutaneously in Duroc and Norwegian Landrace piglets. J Vet Med A Physiol Pathol Clin Med 45: 53-61

Egeli AK, Framstad T, Morberg H 1998b. Clinical biochemistry, haematology and body weight in piglets. Acta Vet Scand 39: 381-393

Ekman KM, Iwanska S 1966. Studies on iron metabolism in normal and anemic nursing pigs. J Vet Med B Infect Dis Vet Public Health 13: 585-595 
Ferguson BJ, Skikne BS, Simpson KM, Baynes RD, Cook JD 1992. Serum transferrin receptor distinguishes the anaemia of chronic disease from deficiency anaemia. J Lab Clin Med 19: 385-390

Furugouri K 1975: Characteristic aspects of iron metabolism in piglets. Jap Agric Res Q 9: 171

Gentry J, Swinkels J, Lindenmann M, Shrama J 1997. Effect of hemoglobin and immunization status on energy metabolism of weaning pigs. J Anim Sci 75: 1032-1040

Groebel K, Hoelzle K, Wittenbrink MM, Ziegler U, Hoelzle LE 2009: Mycoplasma suis invades porcine erythrocytes. Infect Immun 77: 576-584

Hansen SL, Trakooljul N, Spears JW, Liu HC 2010: Age and dietary iron affect expression of genes involved in iron acquisition and homeostasis in young pig. J Nutr 140: 215-236

Hastka J, Lassere JJ, Scwarzbeck A, Hehlmann R 1994: Central role of zinc protoporphyrin in staging iron deficiency. Clin Chem 40: 768-773

Haugegaard J, Wachmann H, Kristensen PJ 2008: Effect of supplementing fast growing late-weaned piglets twice with $200 \mathrm{mg}$ iron dextran intra-muscular. The Pig Journal 61: 69-73

Heinritzi K, Plonait H 1997: Blutkrankheiten. In Plonait H, Bickhardt K (Eds): Lehrbuch der Scheinekrankheiten $\left(2^{\text {nd }}\right.$ edn), Parey Buchverlag Berlin, $190 \mathrm{p}$.

Hirayama KJ, Yasutake K 1998: Free radicals and trace elements. J Trace Elem Exper Med 11: 209-217

Holmgren N 1996: Polyarthritis in piglets caused by iron dextran. Proc $14^{\text {th }}$ IPVS Congress, Bologna, Italy 1996, p. 603

Holter PH, Framstad T, Aulif A, Refsum HE, Sjaastad ØV 1991: Effect of iron treatment erythrocyte parameters in postnatal anemia of the pig. Pediatr Hematol Oncol 8: 1-11

Chen J, Han JH, Guan WT, Chen F, Wang CX, Zhang YZ, Lv YT, Lin G, 2016. Selenium and vitamin E in sow diets: II. Effect on selenium status and antioxidant status of the progeny. Anim Feed Sci Technol 221: 101-110

Ioannou GN, Spector J, Scott K, Rockey DC 2002. Prospective evaluation of a clinical guideline for the diagnosis and management of iron deficiency anemia. Am J Med 113: 281-287

Jain NC 1986: Shalm's Veterinary Haematology (4th edn), pp 240-255

Jolliff JS, Mahan DC 2011: Effect of injected and dietary iron in young pigs on blood hematology and postnatal pig growth performance. J Anim Sci 89: 4068-4080

Kamphues J, Männer K, Netzler C 1992: Effect of a $2^{\text {nd }}$ iron injection in suckling pigs on iron retention and performance before and after weaning, in: Proceedings of the $12^{\text {th }}$ IPVS Congress, August 1992, The Hauge, The Netherlands, $601 \mathrm{p}$.

Kaneko JJ 1980: Clinical Biochemistry of Domestic Animals (3 ${ }^{\text {rd }}$ edn), Academic Press, New York, pp. 649-669

Kaneko JJ 1993: Clinical Biochemistry of Domestic Animals ( $4^{\text {th }}$ edn), Academic Press, New York

Katkiewicz M, Malicka E, Preibisch J 1986: Effect of iron overload on the morphology of some organs in piglets. Pol Arch Vet 25: 75

Kievit GP 2012. Needle-free injection devices versus regular injection techniques for iron supplementation to piglets. Utrecht University Repository (online, accessed 2017-03-11) https://dspace.library.uu.nl/bitstream/ handle/1874/289405/Needle-free_injection_piglets_Diana_Kievit.pdf

Kolb E, Hoffman U 1989. Zur Frage der zweckmässigen Form der Anwendung von Fe-dextran, seiner Verwertung sowie des Mechanismus einer möglichen Schädigung der Ferkel. Mh Vet Med 44: 497-501

Kolb E, Hoffmann U, Nestler K 1992: Untersuchungen über den Gehalt an Eisen, Kupfer und Zink in verschiedenen Geweben (Magen-Darm-Kanal, Lymphknoten, Muskulatur, Herz, Leber, Milz, Niere, Pankreas, Knochenmark) bei neugeborenen Ferkeln nach orale und intramuskulare Verabreichung von Fe-Dextran. Mh Vet Med 47: 271-278

Kubik A, O’Sullivan TL, Harding JCS, Friendship RM 2015: An Investigation of Iron Deficiency and Anemia in Piglets. Centralia Swine Research Update January $28^{\text {th }}$, Kirkton, Ontario 2015

Langie SAS, Kowalczyk P, Tudek B, Zabielski R, Dziaman T, Olinski R, van Schooten FJ, Godschalk RWL 2010: The effect of oxidative stress on nucleotide-excision repair in colon tissue of newborn piglets. Mutat Res-Genet Tox 695: 75-80

Larkin H, Hannan J 1984: Intestinal absorption and structure in iron deficient piglets. Res Vet Sci 36: 199-204

Lehmann P 2001: Anaemia: A major medical problem in the world. Eur Clin Lab 20: 26-30

Lipinski P, Starzynski RR, Canonne-Hergaux B, Tudek R, Olinski P, Kowalczyk P, Dziamam T, Thibaudeau O, Gralak MA, Smuda E, Wolinski J, Usinska A, Zabielskiá R 2010. Benefits and risks of iron supplementation in anemic neonatal pigs. Am J Pathol 177: 1233-1243

Loudenslager MJ, Ku PK, Whetter PA, Ullrey DE, Whitehair CK, Stowe HD, Miller ER 1986: Importance of Diet of dam and colostrum to the biological antioxidant status and parenteral iron tolerance of the pig. J Anim Sci 63: 1905-1914

Loudenslager MJ, Ku PK, Whetter PA, Ullrey DE, Whitehair CK, Stowe HD, Mahan DC, Vallet JL 1997: Vitamin and mineral transfer during fetal development and the early postnatal period in pigs. J Anim Sci 75: 2731-2738

Mahan DC, Newton EA 1995. Effect of initial breeding weight on macromineral and micromineral composition over a 3-parity period using a high-producing sow genotype. J Anim Sci 73: 151-158

McDougall IC, Cavill I, Hulme B, Brain B, McGregor E, McKay P 1992: Detection of functional iron deficiency during erythropoetin treatment: a new approach. Br Med J 304: 225-226

McDowell LR 1992: Iron. In: Minerals in Animal and Human Nutrition. Academic Press Inc. New York, pp. $152-175$ 
Miller ER, Ullrey DE 2007: Baby Pig Anemia, Michigan State University (online, accessed 2017-03-11) http://old.pork.org/filelibrary/factsheets/pigfactsheets/newfactsheets/04-01-07g.pdf

Moritz A, Schwendenwein I, Kraft W 2014. Hämatologie. In Klinische Labordiagnostik in der Tiermedizin (Moritz A, Hrsg.), Verlag Schattauer 7: 79-159

Murphy KA, Friendship RM, Dewey CE 1997. Effect of weaning age and dosage of supplemented iron on the hemoglobin concentrations and growth rate piglets. J Swine Health Prod 5: 135-138

Murray R, Granner DK, Mayes PA, Rodwell VW 2000: Harper's Biochemistry, (25 ${ }^{\text {th }}$ edn). Appleton \& Lange, Stamford, $927 \mathrm{p}$.

Nathanson MH, McLaren GD 1984: Internal iron exchange in normal and iron-deficient Beagle dogs: relationship to iron absorption (abstr). Clin Res 32: 317a

National Research Council 1979: Nutrient Requirements of Domestic Animals. Nutrient Requirements of Swine, Eighth Revised Ed. National Academy of Science-National Research Council, Washington, D.C.

National Research Council 2012: Nutrient Requirements of Swine. Eleventh Revised Edition. National Academic Press, Washington, D.C.

Payne HG, Mullan BP, Nicholls RR, McCulloch SM, Pluske JR, Clarke P 2005: Haematological indices of piglets provided with parenteral iron dextran and creep feed or soil prior to weaning. Manipulating Pig Production X. Proceedings of the Tenth Biennial Conference of the Australasian Pig Science Association (APSA), 27-30 November, Christchurch, New Zealand, 157 p.

Perri AM, Friedship RM, Harding JCS, O'Sullivan TL 2015: An investigation of iron deficiency and anemia in piglets and the effect of iron status at weaning on post-weaning performance. J Swine Health Prod 24: 10-20

Perri AM, Friedship RM, Harding JCS, O’Sullivan TL 2016: An investigation of iron deficiency and anemia in piglets and the effect of iron status at weaning on post-weaning performance. J Swine Health Prod 24: 10-20

Peters JC, Mahan DC 2008: Effects of neonatal iron status, iron injections at birth, and weaning in young pigs from sows fed either organic or inorganic trace minerals. J Anim Sci 86: 2261-2269

Porter DR, Sturrock RD, Capell HA 1994: The use of serum ferritin estimation in investigation of anaemia in patients with rheumatoid arthritis. Clin Exp Rheumatol 12: 179-182

Radostits OM, Blood DC, Gay CC 1994: Iron deficiency. In Radostits OM et al.: Veterinary Medicine Bailliere Tindall, London, pp 1398-1401

Rantzer D, Andersson M, Botermans J, Olsson ACH, Svendsen J 2010: Route of iron supplementation to piglets: effects on hemoglobin, piglet growth and infectious disease. Proceedings of the $21^{\text {st }}$ IPVS Congress, Vancouver, Canada - July 18-21 2010.

Rincker M, Hill G, Link J, Rowntree J 2004: Effects of dietary iron supplementation on growth performance, hematological status, and whole-body mineral concentration of nursery pigs. J Anim Sci 82: 3189-3197

Segales J, Domingo M, Chianini F, Majo N 2004: Immunosuppression in postweaning multisystemic wasting syndrome affected pigs. Vet Microbiol 98: 151-158

Sladic-Simic D, Cvetkovic M 1978: Iron resorption and iron store in piglets after i.m. injection of ${ }^{59} \mathrm{Fe}-\mathrm{iron}$ dextran. Zbl Vet Med A 25: 680

Smith JE 1997: Iron metabolism and its disorders. In Kaneko JJ, Harvey JW, Bruss ML (eds): Clinical Biochemistry of Domestic Animals. Academic Press, pp 223-239

Smith JE, Cipriano JE 1987: Inflammation-induced changes in serum iron analytes and ceruloplasmin of Shetland ponies. Vet Pathol 24: 354-356

Starzynski RR, Laarakkers CM, Tjalsma H, Swinkels DW, Pieszka M, Stys A, Mickiewicz M, Lipinski P 2013. Iron supplementation in suckling piglets: How to correct iron deficiency anemia without affecting plasma hepcidin levels. PloS One 49: e64022

Steinhardt M, Bünger U, Furcht G 1984: Zum Eisenbedarf des Schweines in den ersten 2 Lebensmonaten. Arch Exper Vet Med 38: 497-515

Steinhardt M, Bünger U, Furcht G, Shoenfelder E 1982a: Untersuchungen zur Festlegung von Normalwerten für das rote Blutbild des Ferkels. Arch Exper Vet Med 36: 707-719

Steinhardt M, Bünger U, Furcht G, Shoenfelder E 1982b: Beziehungen zwischen Blutbildung und Eisenstoffwechsel beim Ferkel. Arch Exper Vet Med 36: 729-737

Steinhardt M., Bünger U, Furcht G 1984: Zum Eisenbedarf des Schweines in den ersten 2 Lebensmonaten. Archives of experimental veterinary medicine 38: 497-515

Suominen P, Punnonen K, Rajarnäki A, Irjala K 1998: Serum transferrin receptor and transferrin receptorferritin index identify healthy subjects with subclinical iron deficits. Blood 92: 2934-2939

Süveges T, Glávits R 1976: Piglet losses due to parenteral application of iron-dextran preparations. Acta Vet Acad Sci Hung 26: 257-262

Svoboda M, Drabek J 2005a: Iron deficiency in suckling piglets: etiology, clinical aspects and diagnosis (A review). Folia Vet 49: 104-111

Svoboda M, Drabek J 2005b: Iron deficiency in suckling piglets: parenteral and oral iron administration to piglets (A review). Folia Vet 49: 165-174

Svoboda M, Drabek J 2007: Intramuscular versus subcutaneous administration of iron dextran in suckling piglets. Acta Vet Brno 76: 11-15

Svoboda M, Fricek R, Drabek J 2008: Reticulocyte indices in diagnosis of iron deficiency in suckling piglets. Bull Vets Inst Pulawy 52: 125-130 
Taylor DJ 1989: Piglet anaemia. In Pig Diseases, Fifth Edition, Diamond Farm Book Pubns, pp 212-215

Thomas Ch, Thomas L 2002: Biochemical markers and hematologic indices in the diagnosis of functional iron deficiency. Clin Chem 48: 1066-1076

Tollerz G 1973: Vitamin E, selenium (and some related compounds) and tolerance iron in piglets Acta Agric Scand Suppl 19: 184

Tybirk P, Sloth NM, Jørgensen L 2013: Nutrient Requirement Standards. Pig Research Centre. (Online, accessed 2017-03-14) http://www.Pigresearchcentre.Dk/ /Media/Pdf/Eng/Normer_Naeringstoffer\%20uk/ Nutrient Standards April2013.Ashx

Underwood EJ, Suttle NF 1999: Iron In mineral Nutrition of Lifestock. CAB International, pp 375-396

Van Kempen GJM 1987: Avoid iron deficiency in piglets. Pigs 3: 10-11

Velásquez JI, Aranzazu D 2004: An acute case of iron toxicity on newborn piglets from vitamin E/Se deficient sows. Revista Colombiana de Ciencias Pecuarias 17: 60-62

Venn JAJ, McCance RA, Widdowson EM 1947: Iron metabolism in piglet anaemia. J Comp Pathol Ther 57: 314-325

Vermeer JE, Kuijpers AH, Elbers AR 2002: Comparison of the efficacy of two different iron supplements for anemia prevention in piglets. Tijdschr Diergeneeskd 127: 110-104

Von Bollwahn W, Knörl H, Heinritzi K 1983: Klinik und Diagnose des latenten Eisenmangels beim Ferkel. Prakt Tierartz 64: 294-299

Vrigazov A, Dilov P 1976: Resorption and distribution of iron-dextran praparations in pigs, calves, and lambs. Proceedings of the $20^{\text {th }}$ World Veterinary Congress, Thessaloniki 1: 436-440

Wattanakul W, Bulman CA, Edge HL, Edwards SA 2005: The effect of creep feed, presentation method on feeding behaviour, intake and performance of suckling piglets. Appl Anim Behav Sci 92: 27-36

Wei KQ, Xu ZR, Luo XG, Zeng LL, Chen WR, Timothy MF 2005, Effects of iron from an amino acid complex on the iron status of neonatal and suckling piglets. Am J Anim Sci 18: 1485-1491

Wilhelm R 1998: Iron toxicity in newborn pigs. In Aiello SE (Ed): The Merck Veterinary Manual, Merck \& co., inc., $2071 \mathrm{p}$.

Yu IT, Lin J, Wu JF, Yen, HT, Lee SL, Yang TS 2002: Reevaluation of the necessity of iron injection to newborn piglets. Asian-Austr Anim Sci 15: 79-83

Zimmermann W 1995: Auswirkungen diverser Anämieprohylaxeformen auf die Blutparameter der Saugferkel. Dtch Tierärtz Wschr 102: 32-38 